\title{
IAMJ
}

INTERNATIONAL

AYURVEDIC

MEDICAL JOURNAL

ISSN: 2320-5091

Impact Factor: 6.719

\section{PANEEYA KSHARA IN GALLBLADDER POLYP - A CASE STUDY}

\author{
Nagaratna $^{1}$, Srinivas Masalekar ${ }^{2}$ \\ ${ }^{1}$ P.G. Scholar Dept. of Shalya Tantra Govt. Ayurvedic Medical College and Hospital, Bengaluru, Karnataka, India \\ ${ }^{2}$ Associate Professor Dept. of Shalya Tantra Govt. Ayurvedic Medical College and Hospital, Bengaluru, \\ Karnataka, India
}

Corresponding Author: nagaratnayu@gmail.com

\section{https://doi.org/10.46607/iamj4008122020}

(Published online: December 2020)

Open Access

(C) International Ayurvedic Medical Journal, India 2020

Article Received: 10/11/2020 - Peer Reviewed: 16/11/2020 - Accepted for Publication: 22/11/2020

\section{D) Check for updates}

\section{ABSTRACT}

Gall bladder polyps are growths or lesion resembling growths in the wall of the Gall bladder. Most small Polyps (less than $1 \mathrm{~cm}$ ) are not cancerous but the most dreaded complication of the Gall bladder Polyp is Adenocarcino$\mathrm{ma}^{1}$. Direct reference of Gall bladder polyp is not available in Ayurveda. The disease can be correlated to Pittashoshaja shola. In this case study, a 25-year-old female diagnosed with Gall bladder Polyp was administered Paaneeya Kshara for 28 days. Assessment was done for pain and size of Polyp. Significant improvement was observed after treatment.

Keywords: Gallbladder Polyp, Paneeya Kshara.

\section{INTRODUCTION}

Direct reference of Gall bladder polyp is not available in Ayurveda. The disease can be correlated to Pittashoshaja shola. In this case study, a 25-year-old female diagnosed with Gall bladder Polyp was administered Paaneeya Kshara for 28 days. Assessment was done for pain and size of Polyp. Significant improve- ment was observed after treatment. Gall bladder Polyps are growth or lesion resembling growths (polypoid lesions) in the wall of the Gallbladder. True polyps are abnormal accumulations of mucus membrane tissue that would normally be shed by the body. Polypoid lesion of the gallbladder affects approxi- 
mately $5 \%$ of the adult population. The causes are uncertain, but there is a definite correlation with increasing age and the presence of gallstones (cholelithiasis). Most affected individuals do not have symptoms. Gallbladder polyps are usually found incidentally when examining the abdomen by Ultrasound for other conditions, usually abdominal pain. Gall bladder Polyps (less than $1 \mathrm{~cm}$ ) are not cancerous but the most dreaded complication of the Gallbladder polyp is Adenocarcinoma ${ }^{1}$. Cholesterolosis is characterized by an outgrowth of the mucosal lining of the gallbladder into fingerlike projections due to the excessive accumulation of cholesterol and triglycerides within macrophages in the epithelial lining. These cholesterol polyps account for most benign gall bladder polyps. Diagnosis is typically by Ultrasound or CT imaging. Most polyps are benign and do not need to be removed. Surgical removal of the gallbladder(cholecystectomy) is recommended when a gallbladder polyp larger than $1 \mathrm{~cm}$ is found, even if the person has no symptoms clearly related to the polyp. Laparoscopic surgery is an option for small or solitary polyps $^{2}$. Direct reference of Gallbladder polyp is not available in Ayurveda. The disease can be correlated to Pittashoshaja shola. Vaidya Kashinath Shashtri the author of Rasa Tarangini quotes under the context of Narikela Lavana Guna Karma that, Vata prakopa in the Pittashaya leads to the Shoshana of Pitta Dosha present in the Pittashaya which later leads to Shoola ${ }^{3}$. This shows the excessive accumulation of cholesterol and triglycerides which later leads to the finger like projection named as Polyp.

\section{Case Report:}

A 25-year-old female married presented with complaints of pain abdomen and irregular menstruation for 2 months, so she consulted nearby hospital and there they advised for Ultrasonography of abdomen and pelvis. Reports revealed that the presence of Gallblad- der polyp and posterior wall intramural uterine fibroid. So, she consulted Shalya Tantra OPD of SJIIM hospital, GAMC Bengaluru. Interrogation revealed that the patient had taken ANALGESICS but did not get any relief and approached for better management. Patient is not a known case of Diabetic mellitus and Hypertension or underwent any surgery. On physical examination pulse rate was $76 / \mathrm{min}$, regular with normal volume. Blood pressure was 120/80 mmHg.

Systemic examination- Cardiovascular system- $\mathrm{S}_{1} \mathrm{~S}_{2}$ heard, no added sounds., Central nervous systemconscious, oriented, Respiratory system- bilateral air entry clear, Per abdomen- soft, non-tender.

Local examination- Inspection-oral cavity- hygiene is good, no dental caries, Shape of abdomen - flat, Shape of umbilicus- inverted, Palpation-superficialno tenderness, Deep- no tenderness, no organomegaly, Percussion - tympanic note, Auscultation -3 peristalsis/min

Investigations - $\mathrm{Hb} \%-14.6 \mathrm{gm} \%$; ESR- $34 \mathrm{~mm} / \mathrm{hr}$; RBS- 96mg/dl; CT- 2'4'”; BT- 4'2'”; HIV- NR; HbsAG - Negative.

Abdomino - pelvic sonography (22/10/2019) Gall bladder $-2.5 \mathrm{~mm}$ nonmobile hyperechoic foci noted suggests Polyp., Posterior wall intramural uterine fibroid.

Nidana: Ahara - Ruksha Ahara, Mamsa Sevana, Vihara - Avyayama, Manasika - Chinta, Krodha

Samprapti- Vata Prakopa in the Pittashaya leads to the shoshana of Pitta Dosha present in the Pittashaya which later leads to Shoola .

Diagnosis: Gall bladder polyp

Treatment Given: Patient is advised to take the combination of 2grams each of Narikela Lavana, Navasadara and Yava Kshara orally with Jala (Water) once daily in empty stomach in the morning, every day for 28 days.

\section{Criteria for Assessment-}

1. Visual analogue scale was used to get an assessment of pain relief after each sitting. Visual analogue scale noted as,

0-----1-----2------3-----4-------5----6----7-----8----9----10

0-no pain, 1-3 is mild pain, 4-7 moderate pain, 8-10 severe pain. 


\section{Observation and Result-}

2. Pain

\begin{tabular}{|l|l}
\hline BT & AT \\
\hline 3 & 0
\end{tabular}

Clinical examination of the patient revealed regression of symptoms in 28 days.

3. Size of the polyp

\begin{tabular}{|l|l}
\hline BT & AT \\
\hline $2.5 \mathrm{~mm}$ & Nil
\end{tabular}

\section{DISCUSSION}

Discussion is the important part of any research work. It provides a platform for re-examining the whole work, which is a key part of any scientific and methodological research work, even in classics, this has been highlighted and accepted in the name of Vimarsha i.e. discussion before coming to any conclusion. The reference of Pittashoshaja Shula is dealt in Rasa Tarangini. Under the context of Narikela Lavana Guna Karma, Rasa Tarangini Kaara quotes, Vata prakopa in the Pittashaya causes the Shoshana of Pitta Dosha in the Pittashaya which later leads to the manifestation of Shula. By considering Gall bladder polyp as Pittashoshaja Shola, the present study is carried out to know the efficacy of Paneeya Kshara in Gallbladder polyp, Pittashoshaja shoola is said to be Tridoshaja Vyadhi, still Vata and Kapha plays a major role in the formation of the poly. Ruksha Guna of Apaana Vata and Ushna Guna of Pitta hardens the Kapha which acts as nidus, upon which aggregation of Dosha takes place and finally results in Pittashoshaja Shula. Kshra is a remedy formed by process of Bhasmikarana, filtration, evaporation termed as Sanskaras. During the process of drying it undergo kala, vata and Atapa Sanskara. Which makes the drug dry and same Gunas of Vata. During Bhasmikarana process it undergo Agnisanskara which make the drug Kaphagna and Vatagna. Afterwards it gets settled with water for whole night here Jala and Prithvimahabhuta will act, build capacity to break. Further, the more it again undergoes Agnisanskara. During the whole process Rasa, Veerya, Vipaka of Dravya all changes and a new formulation i.e. Kshara is obtained. Which is of Lavana Rasa, Ushna Veerya, it dissolves the polyp. Narikela Lavana is said to be $\mathrm{Pa}$ - chaka, Amla Pitta Hara, Pittashamaka, Pittashoshaja Shoola Hara. Here, Narikela Lavana contains albumin, globulin, amino acids and acetic acids. Hence it dissolves the polyp. Navasadara is said to be Tridoshgna, Sukshma, Jataragni Deepaka, Pitta Saaraka. It acts as expectorant. Yava kshara is said to be Ruksha, Kapha Pittashamaka, Shoolahara, Medohara, Agnivardhaka and Gulma Hara. It is useful in dyspepsia, abdominal pain, vomiting and obesity. It has diuretic property.

\section{CONCLUSION}

The combination of Narikela Lavana, Navasadara Yuktha Yava Kshara shown significant result in both subjective and objective parameter. The preparation of Narikela Lavana, Navasadara Yuktha Yava Kshara is simple, palatable, easy for administration, free from side effects and therapeutic efficacy is good. So, it can be adopted as a remedy for treatment of Gallbladder polyp.

\section{REFERENCES}

1. A concise textbook of Surgery, by Somen Das, $9^{\text {th }}$ Edition, Published by Dr. S. Das 13, Old Mayors Court, Kolkata -700005 India, The biliary system $-37^{\text {th }}$ chapter, Page no.879-880.

2. https://en.m.wikipedia.org $>$ wiki

3. Rasa Tarangini by Vaidya Sadanand Sharma, Prasadini Vyakhya by Shree Haridatta shashtri, edited by Vaidya Kashinath shashtri, Published by Chaukamba Sanskrith Sansthan Varanasi, Reprint - 2000, 14 ${ }^{\text {th }}$ Chapter - Narikela Lavana Guna karma, Verse-349,350.

4. SRB'S manual of surgery, by sriram bhat $M, 6^{\text {th }}$ edition, published by Jaypee brothers' medical 
publishers(p) 1td, Gall bladder $-12^{\text {th }}$ chapter, page no. $650-651$

5. Bailey and Loves, "the gall bladder and bile ducts", short practice of surgery, $27^{\text {th }}$ edition,
Hodder Arnald publications, part 2, chapter 67 gall bladder and bile ducts, Pg- 1201 .

\section{Photographs:}

Before and After treatment Ultrasound reports

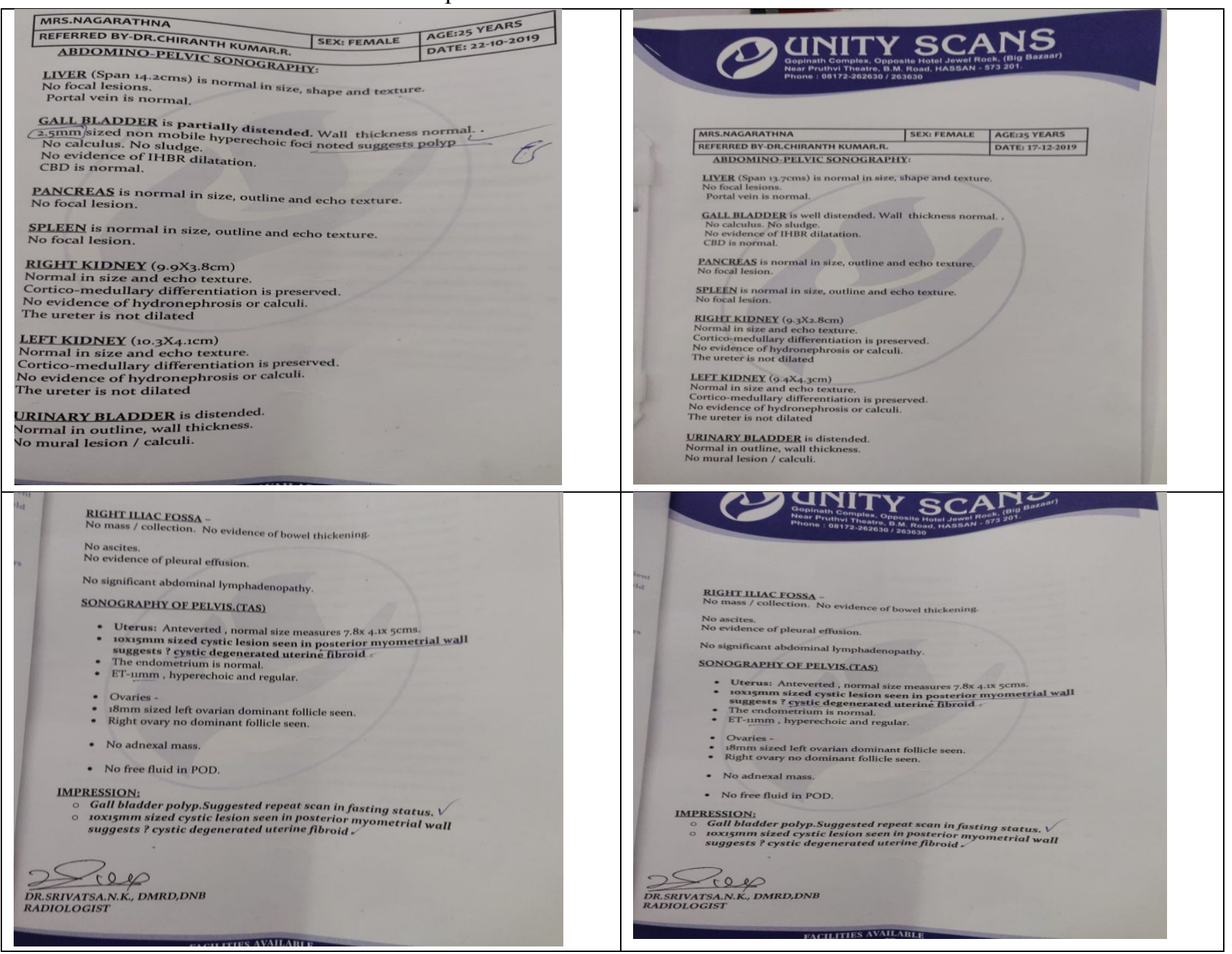

\section{Source of Support: Nil}

\section{Conflict of Interest: None Declared}

How to cite this URL: Nagaratna \& Srinivas Masalekar: Paneeya Kshara In Gallbladder Polyp - A Case Study. International Ayurvedic Medical Journal \{online\} 2020 \{cited December, 2020\} Available from: http://www.iamj.in/posts/images/upload/5427_5430.pdf 